\title{
Kajian Retorika Struktur Argumen Karya Tulis IImiah Siswa Hasil Ekstrakurikuler Karya IImiah Remaja SMA
}

\author{
Eka Darlina \\ (corresponding author) \\ SMA Negeri 6 Kota Bengkulu \\ Email: darlina.pasca@gmail.com \\ Dian Eka Chandra Wardhana \\ Program Studi Magister Pendidikan Bahasa Indonesia, Universitas Bengkulu \\ Email: dec.wardhana@unib.ac.id \\ Ria Ariesta \\ Program Studi Magister Pendidikan Bahasa Indonesia, Universitas Bengkulu \\ Email: riaariesta17@gmail.com
}

\begin{abstract}
APA Citation: Darlina, E., Wardhana, D.E.C., \& Ariesta, R. (2021). Kajian Retorika Struktur Argumen Karya Tulis IImiah Siswa Hasil Ekstrakurikuler Karya IImiah Remaja SMA. Silampari Bisa: Jurnal Penelitian Pendidikan Bahasa Indonesia, Daerah, dan Asing, 4(1), 159-172. https://doi.org/10.31540/silamparibisa.v4i1.1290
\end{abstract}

\begin{abstract}
Abstrak
Tujuan penelitian ini adalah mendeskripsikan struktur argumen latar belakang karya ilmiah yang tertuang pada pendahuluan karya tulis ilmiah ekstrakurikuler KIR siswa SMA. Metode penelitian menggunakan metode deskriptif kualitatif. Teknik pengumpulan data menggunakan teknik dokumentasi yang bersumber dari karya tulis ilmiah siswa ektrakulikuler karya ilmiah remaja SMA. Teknik analisis data dengan langkah-langkah pengkodean, pengklasifikasian, dan penafsiran. Uji keabsahan dengan member check dan uji pakar wacana. Hasil penelitian menunjukkan bahwa struktur argumen karya tulis ilmiah siswa hasil ektrakulikuler karya ilmiah remaja SMA berpola: 1) pernyataan, pembenaran, dan kesimpulan; 2) pernyataan, pembenaran, kesimpulan, dan subkesimpulan; 3) pernyataan, subpernyataan, pembenaran, dan kesimpulan; 4) pernyataan, pembenaran, subpembenaran, dan kesimpulan; 5) pernyataan dan pembenaran. Struktur argumen dalam karya tulis ilmiah sudah baik, walaupun ada yang belum lengkap terutama belum dihadirkannya kesimpulan. Hasil penelitian ini diharapkan agar ditindaklanjuti khususnya bagi pelatih ektrakulikuler karya ilmiah remaja SMA untuk memberikan pemahaman kepada siswa dalam menulis paragraf argumentasi dengan menggunakan variasi pola argumen yang lengkap yaitu pernyataan, pembenaran, dan kesimpulan.
\end{abstract}

Kata kunci: retorika, struktur argumen, karya tulis ilmiah, siswa 


\title{
Rhetoric Study of the Structure of the Argument of Student Scientific Papers from the Results of Extracurricular Youth Scientific Works in Senior High School
}

\begin{abstract}
The purpose of this study was to describe the structure of the background arguments for the scientific papers contained in the introduction of KIR extracurricular scientific papers for high school students. The research method uses a qualitative descriptive method. The data collection technique uses documentation techniques that are sourced from extracurricular scientific papers by high school adolescents. Data analysis techniques with the steps of coding, classification, and interpretation. Validity test with member check and discourse expert test. The results showed that the argument structure of students' scientific papers extracurricular activities of high school adolescents was patterned: 1) claim, justifications, and conclusions; 2) claim, justifications, conclusions, and sub-conclusions; 3) claim, subclaim, justifications, and conclusions; 4) claim, justifications, sub-justifications and conclusions; 5) claim and justification. The structure of the argument in scientific writing is good, although some are incomplete, especially the conclusion that has not been presented. The results of this study are expected to be followed up, especially for the extracurricular trainer of high school adolescent scientific papers to provide understanding to students in writing argument paragraphs using a complete variation of argument patterns, namely claim, justifications, and conclusions.
\end{abstract}

Keywords: rhetoric, argument structure, scientific writing, students

\section{A. Pendahuluan}

Ekstrakurikuler merupakan salah satu kegiatan belajar tambahan siswa SMA. Salah satu ekstrakurikuler siswa yakni karya ilmiah remaja (KIR), dengan ikut kegiatan menulis karya ilmiah remaja ini diharapkan mampu mendorong kreativitas siswa dalam mengasah kemampuan berbahasa, meningkatkan daya pikir, menampung pemikiran kritis dan ide siswa. Aspek keterampilan berbahasa tersebut meliputi menyimak, berbicara, menulis, dan membaca (Jauhari, 2018:17). Khususnya, melalui tulisan terlihat apakah seseorang memiliki keterampilan dalam berbahasa yang baik atau tidak.

Suatu karya ilmiah yang dimulai dari argumen pendahuluan haruslah ditulis dan dikemas semenarik mungkin karena pada bagian inilah penulis memperkenalkan sekaligus menggiring pembaca terhadap pokok tulisan penulis yang akan penulis sampaikan. Bagian ini sangat menentukan pembaca untuk melanjutkan kegiatan membacanya atau tidak (Suparno, 2007). Bila argumen pada pendahuluan telah tersampaikan secara menarik, maka pembaca tertarik untuk terus membaca suatu karya ilmiah yang disampaikan ke bagian berikutnya. Pembaca dengan mudah memahami dan menginterpretasi isi suatu karya ilmiah yang disampaikan penulis.

Penulisan suatu karya ilmiah tidak terlepas dari retorika seorang penulisnya. Retorika sangat terkait dengan teknik pemakaian bahasa sebagai seni yang didasarkan pada pengetahuan yang tersusun baik (Keraf, 2010:30). Beretorika dibutuhkan pengetahuan, penggunaan bahasa yang tepat tentang objek yang disampaikan karena itu retorika harus dipelajari. Kurangnya kesadaran akan retorika dapat menyebabkan gangguan berkomunikasi, Gangguan ini dapat berupa kegagalan komunikasi. Menurut Trianto (2000) kegagalan komunikasi ini dapat disebabkan 
Eka Darlina, Dian Eka Chandra Wardhana, Ria Ariesta

Kajian Retorika Struktur Argumen Karya Tulis IImiah Siswa Hasil Ekstrakurikuler Karya IImiah Remaja SMA

penggunaan retorika yang keliru atau salah terap. Retorika seorang penulis dalam berargumen mestinya tersusun baik, disampaikan dengan bahasa yang tepat agar tidak terjadi kegagalan pemahaman.

Retorika argumen mengandung kesatuan wacana yang utuh, cara penyajian (delivery) haruslah ditulis dengan baik disertai penggunaan gaya bahasa yang baik (Noermanzah dkk., 2018). Retorika dalam berargumen sangat berkaitan erat dengan teknis pengungkapan yang tepat dan daya pembuktian serta penilaian yang tepat (Sulistyarini \& Zainal, 2020:23; Noermanzah dkk., 2020). Melalui pengungkapan, pembuktian, dan penilaian akan menghasilkan suatu kesepakatan bersama dalam berargumentasi antara pembicara dengan pendengar atau antara penulis dan pembaca. Begitu pentingnya retorika argumen sebagai upaya berargumentasi dengan baik, maka perlu pemahaman terhadap retorika argumen. Guna mendapatkan gambaran jelas terkait retorika argumentasi karya ilmiah remaja diperlukan teori yang relevan untuk untuk digunakan sebagai pisau pembedah, sehingga diperoleh gambaran retorika argumentasi penulis yang tepat dan benar.

Retorika merupakan seni atau teknik pemakaian serta penataan bahasa dengan tepat dalam berkomunikasi baik lisan maupun tulisan (Noermanzah dkk., 2017). Ini berarti pembicara atau penulis dituntut memiliki pengetahuan dan memahami tentang retorika untuk memperoleh gambaran seni dan teknik penataan atau pembentukkan komunikasi yang baik dapat dilakukan dengan kajian atau analisis retorika. Retorika seni dalam menulis, esensi analisis retorika bagaimana menciptakan makna, mengkonstruksi agar suatu teks membuat pembaca bertindak (Trianto, 2009:8). Analisis retorika kemudian membantu pembaca memahami secara eksplisit (bukan sekedar implisit) bagaimana bahasa teks bekerja dan bagaimana kita dapat menggunakan bahasa bekerja untuk kita.

Argumen merupakan proses data fakta atau bukti yang menunjukkan hasil dari suatu logika. Argumen dapat diterapkan apabila kita telah mencapai kesimpulan dengan cara perhitungan atau dengan lompatan sederhana (Toulmin, 2003). Hingga penyajian argumen pada suatu karya semestinya terbentuk dari pola-pola yang ada pada struktur argumen yang diharapkan menjadi suatu karya ilmiah yang baik dan mudah untuk dimengerti.

Fokus penelitian dirumuskan bagaimana struktur argumen pada karya tulis siswa siswa ekstrakurikuler karya ilmiah remaja SMA. Tujuan dari penelitian yakni mendeskripsikan struktur argumen latar belakang karya ilmiah yang tertuang pada pendahuluan pada karya tulis ilmiah siswa ekstrakurikuler karya ilmiah remaja SMA. Penelitian ini diharapkan bermanfaat secara teoritik maupun praktis.

Penelitian ini penulis menggunakan analisis model bottom-up. Penggunaan analisis ini dikarenakan suatu paragraf argumen tidak dapat dicapai sekaligus dengan hanya satu pernyataan, satu pembenaran atau satu kesimpulan saja, tetapi melalui beberapa argumen kecil yang saling mendukung, sub-pernyataan, subpembenaran dan sub-kesimpulan yang masing-masing sub tersebut didukung oleh elemen lain (Safnil, 2010:52). Model analisis bottom-up adalah model analisis yang digunakan untuk menguji karangan argumen dengan memandang argumen sebagai proses monolog.

Fokus analisis bottom-up adalah melihat hubungan antara urutan tindak tutur dalam karangan argumentatif hanya pada bagian masalah. Urutan paragraf pada bagian masalah ini memiliki tindak tutur terdiri dari pernyataan, pembenaran dan kesimpulan. Penulis memulai bagian masalah dengan mengajukan suatu claim atau

Silampari Bisa: Jurnal Penelitian Pendidikan Bahasa Indonesia, Daerah, dan Asing

Vol. 4, No. 1, 2021 
Eka Darlina, Dian Eka Chandra Wardhana, Ria Ariesta

Kajian Retorika Struktur Argumen Karya Tulis IImiah Siswa Hasil Ekstrakurikuler Karya IImiah Remaja SMA

pernyataan mengenai pendapat penulis untuk pembaca, dan klaim ini didukung dengan pembenaran yang berbentuk pengalaman, data dan fakta statistik atau kejadian otentik. Bagian terakhir, penulis mengemukakan suatu induksi atau kesimpulan logis yang diambil dari pembenaran dan pernyataan sebelumnya Toulmin dkk dalam Safnil (2010:48). Urutan tindak tutur pada bagian masalah dalam sebuah karangan argumentatif digambarkan sebagai berikut.

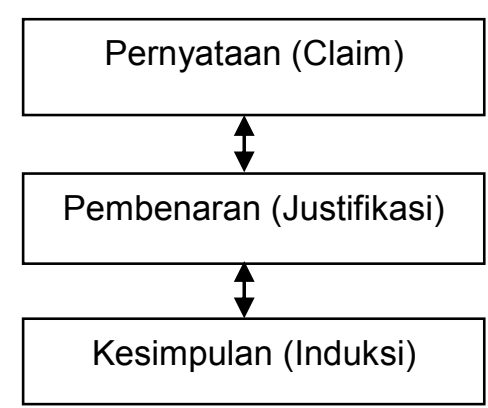

\section{Gambar 1. Proses Monolog pada Bagian Masalah Karangan Argumentatif}

Penelitian tentang retorika ini merupakan penelitian yang bersifat melengkapi beberapa penelitian sebelumnya, diantaranya oleh Trianto (2000), Fitri (2002), Atmaja (2016), Yati (2018), Abduh dkk. (2019), dan Noermanzah dkk. (2018) baru sebatas retorika argumen dalam wacana humor dan pidato. Hal berbeda pada penelitian ini penulis fokus pada struktur argumen pada karya ilmiah remaja SMA di Kota Bengkulu menggunakan pola analisis bottom up. Peneliti mendeskripsikan karakteristik retorika argumen siswa yang difokuskan pada argumentasi karya ilmiah khususnya tertuang dalam latar belakang masalah yang meliputi struktur generik teks argumentasi berdasarkan analisis struktur pola-pola retorika teks argumentasi berdasarkan analisis bottom-up atau struktur monolog dalam teks argumentasi.

\section{B. Metode Penelitian}

Metode pada penelitian ini menggunakan metode deskriptif kualitatif. Metode deskriptif ini berusaha untuk menyesuaikan dengan kenyataan pada saat penelitian itu dilakukan. Metode deskriptif merupakan jenis penelitian pengukuran yang cermat terhadap fenomena tertentu yang digunakan untuk membuat pendeskripsian secara sistematis, aktual, akurat, dan aktual terhadap objek yang diteliti (Susetyo, 2010:11).

Pengumpulan data menggunakan teknik dokumenter yaitu meneliti dokumendokumen tentang gejala atau fenomena yang akan terjadi di lapangan. Data yang digunakan dalam penelitian ini berupa data primer berupa karya ilmiah remaja. Sedangkan data sekunder merupakan data yang diperoleh dari arsip, buku, dan dokumen lainnya yang dapat membantu penelitian ini.

Dalam menentukan sampel karya ilmiah remaja ini penulis menggunakan teknik purposive sampling. Purposive sampling yaitu teknik pengambilan sampel dengan tujuan tertentu (Sugiyono, 2017:84). Sampel adalah bagian dari jumlah yang dimiliki oleh populasi tersebut, sehingga untuk pengambilan sampel menggunakan cara-cara tertentu dengan pertimbangan-pertimbangan yang ada. Dari beberapa SMA yang ada di Kota Bengkulu, penulis mengambil 5 sekolah dengan pertimbangan aktif dan yang kurang aktif pada kegiatan ekstrakurikuler karya ilmiah remaja. Seterusnya peneliti

Silampari Bisa: Jurnal Penelitian Pendidikan Bahasa Indonesia, Daerah, dan Asing Vol. 4, No. 1, 2021 
mengambil data sepuluh karya ilmiah remaja dengan alasan keterwakilan karya ilmiah yang dipilih oleh sekolah masing-masing untuk ikut dalam kegiatan kejuaraan karya ilmiah remaja dan yang belum dipilih oleh sekolah dengan pertimbanganpertimbangan tertentu. Dengan teknik ini semua karya ilmiah remaja dapat terwakili.

Penelitian dilakukan pada SMA yang ada di Kota Bengkulu yaitu SMAN 06 Bengkulu, SMAN 2 Bengkulu, SMAN 5 Bengkulu, SMAN 8 Bengkulu, dan SMAN 9 Bengkulu, yang mana ini mewakili dari sekolah SMA yang ada di Kota Bengkulu. Peneliti mendapatkan data berupa teks latar belakang pada karya ilmiah remaja SMA yang ada di Kota Bengkulu sebanyak sepuluh teks, dari sepuluh teks penulis penulis mendapatkan 43 pola paragraf argumen, 40 pola paragraf argumen yang dapat penulis analisis sedangkan 3 paragraf tidak dapat penulis analisis karena hanya terdiri dari satu paragraf argumen.

Prosedur analisis data dengan cara yaitu karangan dibaca secara hati-hati untuk memahami ide-idenya, kemudian dibagi ke dalam unit-unit (T-Unit) kalimat. Komponen analisis isi antara lain, pengkodean, pengklasifikasian, dan penafsiran (Krippendorff, 1993:69). Dengan mengkombinasikan analisis tersebut, maka tahap analisis data yang digunakan dalam penelitian ini adalah sebagai berikut: 1) memberi kode pada setiap sumber data yang diperoleh, misalnya teks 01 penulis memberi pengkodean 01/06/18/NIK dan seterusnya sampai kode 10;2) Membaca secara hatihati dan memahami seluruh isi teks sub-bab latar belakang (argumentasi) yang diperoleh; 3) memasukkan wacana/teks ke dalam tabel dengan memisahkan masingmasing unit gramatikal atau t-unit, misalnya kalimat klausa diberi nomor kode t-unit 01, hingga dapat dikelompokkan pada masing-masing pola yang ditemukan; 4) menganalisis masing-masing t-unit pada teks dengan memberi kode untuk bagianbagian teks berdasarkan tindak tutur secara lebih rinci pernyataan/claim, pembenaran/justification, dan kesimpulan/induksi pada tiap paragraf wacana pendahuluan; serta 5) mendeskripsikan dan membahas hasil analisis data dan menarik kesimpulan.

\section{Hasil Penelitian dan Pembahasan \\ 1. Hasil Penelitian}

Hasil analisis ditemukan pola paragraf argumen sebanyak 5 pola, yakni pola I yaitu pernyataan-pembenaran-kesimpulan), pola II yaitu pernyataan-pembenaran), pola III yaitu pernyataan-sub pernyataan-pembenaran-kesimpulan, pola IV yaitu pernyataan-pembenaran-sub pembenaran-kesimpulan, dan pola $\mathrm{V}$ yaitu pernyataanpembenaran-kesimpulan-sub kesimpulan.

\section{a. Pola Pernyataan, Pembenaran dan Kesimpulan (Pola I)}

Pola I yaitu pernyataan-pembenaran-kesimpulan berupa wacana penulisan diawali dengan pernyataan penulis untuk memperkenalan masalah yang terjadi didukung dengan pembenaran berupa fakta dan data otentik guna mengemukakan suatu kesimpulan dari pembenaran tersebut urutan tindak tutur pada bagian masalah pada pola I dalam teks karya ilmiah remaja siswa sesuai digambarkan (Safnil, 2010:48) sebagai berikut. 
Eka Darlina, Dian Eka Chandra Wardhana, Ria Ariesta

Kajian Retorika Struktur Argumen Karya Tulis IImiah Siswa Hasil Ekstrakurikuler Karya IImiah Remaja SMA

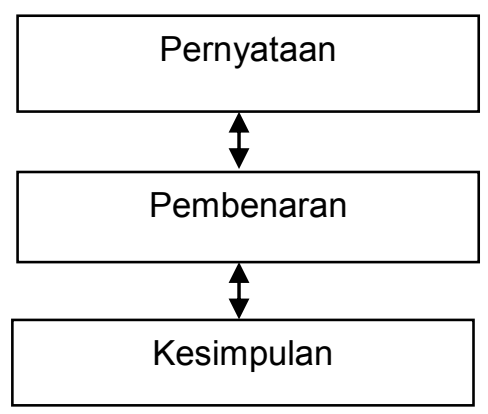

Gambar 2. Pola I berupa Pernyataan, Pembenaran, dan Kesimpulan

Pola ini ditemukan pada teks kode 01/06/18/NIK paragraf 2, teks 06/05/18/ABU paragraf I, teks 07/08/19/NS paragraf 2. Kemudian, pada teks 08/08/19/CLDHP paragraf 6 dan teks 09/09/18/TA pada paragraf 4. Teks 08/08/19/CLDHP pada paragraf 2, teks 08/08/19/CLDHP pada paragraf 3, teks 08/08/19/CLDHP pada paragraf 4 , teks 08/08/19/CLDHP pada paragraf 5, teks 08/08/19/CLDHP pada paragraf 8 , dan teks 09/09/18/TA pada paragraf 2.

\section{b. Pola Pernyataan, Pembenaran, Kesimpulan, dan Sub-Kesimpulan (Pola II)}

Pola II yaitu pernyataan-pembenaran-kesimpulan-sub kesimpulan, penulis mengawali dengan pernyataan meneruskan wacana dengan pembenaran dan pada akhir wacana, penulis menyampaikan kesimpulan lalu penulis menguatkan subkesimpulan. Struktur argumen pada karya tulis siswa ekstrakurikuler karya ilmiah remaja pola II dapat digambarkan sebagai berikut.

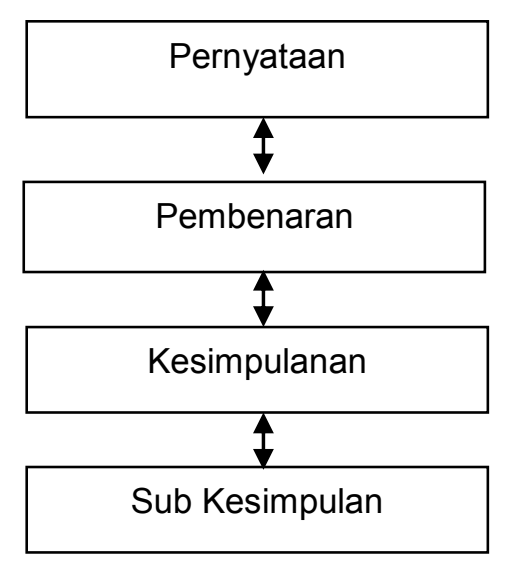

Gambar 3. Pola II berupa Pernyataan-Pembenaran-Kesimpulan-Sub Kesimpulan

Pola ini dapat ditemukan pada teks 02/06/18/NIK paragraf 4, dan teks 04/02/19/PA paragraf 3. Ditemukan karya ilmiah remaja SMA struktur argumen yang tidak berpola, yang terdiri dari satu paragraf saja, pola ini ditemukan sebanyak 3 kalimat atau $7 \%$, Pola ini dapat ditemukan pada teks 09/09/18/TA paragraf 1 dan paragraf 6 dan teks 10/09/18/DA paragraf 3 .

Peneliti membandingkan antara karya ilmiah remaja yang ikut serta pada kegitan perlombaan dan belum diikutsertakan. Berdasarkan analisis ditemukan teks karya 
Eka Darlina, Dian Eka Chandra Wardhana, Ria Ariesta

Kajian Retorika Struktur Argumen Karya Tulis IImiah Siswa Hasil Ekstrakurikuler Karya IImiah Remaja SMA

ilmiah remaja yang diikutsertakan yaitu teks 01/06/18/NIK, 02/06/18/NIK, 03/02/21/ABS, 05/05/20/INR, 08/08/19/CLDHP dan teks 10/09/18/DA ditemukan pola yang bervariasi. Analisis penulis menemukan pola paragraf argumen yang keseluruhan paragrafnya sudah memenuhi elemen paragraf berdasarkan analisis bottom-up yaitu pada teks 03/02/21/ABS, dan 05/05/20/INR hal ini seiring dengan prestasi yang didapat oleh karya ilmiah ini yakni menjadi juara pada tingkat provinsi hingga mewakili pada kegiatan kejuaraan tingkat nasional dan teks ini peneliti ambil dari SMAN 2 Bengkulu dan SMAN 5 Bengkulu yang mana masing-masing sekolah ini merupakan sekolah berprestasi di Kota Bengkulu. Teks 04/02/19/PA, 06/05/18/ABU, 07/08/19/NS dan 09/09/18/TA yang mewakili karya ilmiah remaja yang belum diikutsertakan pada kegiatan kejuaraan, analisis penulis ditemukan pola paragraf yang sangat bervariatif yang mana didominasi pola paragraf argumen tidak lengkap atau pola dua meskipun ada satu teks ditemukan memenuhi elemen paragraf argumen berdasarkan analisis bottom-up yaitu pada teks 07/08/19/NS. Dengan demikian, penulis menyimpulkan bahwa penulisan karya tulis ilmiah remaja perlu perbaikan.

\section{c. Pola Pernyataan, Sub-pernyataan, Pembenaran , dan Kesimpulan (Pola III)}

Pola III berupa pernyataan-sub pernyataan-pembenaran-kesimpulan,. penulis memulai wacana dengan menyampaikan pernyataan lalu mempertegas dengan subpernyatan didukung pembenaran lalu penulis menyimpulkan. Bagian masalah pada pola III terdapat pernyataan berulang atau penekanan kembali oleh penulis sesuai digambarkan sebagai berikut.

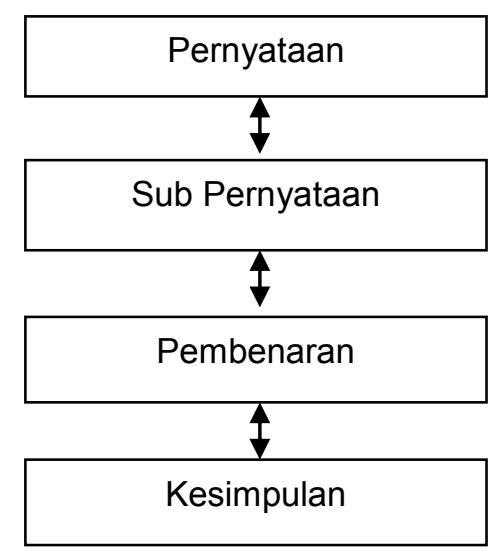

Gambar 4. Pola III berupa Pernyataan-Sub Pernyataan-Pembenaran-Kesimpulan

Pola III ini dapat ditemukan pada teks kode 04/02/19/PA paragraf 1, teks kode 04/02/19/PA paragraf 2, teks 05/05/20/INR paragraf 1 , dan teks 05/05/20/INR paragraf 4.

\section{d. Pola Pernyataan, Pembenaran, Sub-Pembenaran, Kesimpulan (Pola IV)}

Pola IV berupa pernyataan-pembenaran-sub pembenaran-kesimpulan, penulis mengawali wacana tulisan dengan pernyataan lalu penulis menyampaikan pembenaran yang dipertegas lagi dengan sub-pembenaran yang berupa fakta dan data pada akhir wacana penulis menyampaikan kesimpulan. Struktur argumen pada karya tulis ilmiah siswa SMA pola IV dapat digambarkan pada bagan berikut. 
Eka Darlina, Dian Eka Chandra Wardhana, Ria Ariesta

Kajian Retorika Struktur Argumen Karya Tulis IImiah Siswa Hasil Ekstrakurikuler Karya IImiah Remaja SMA

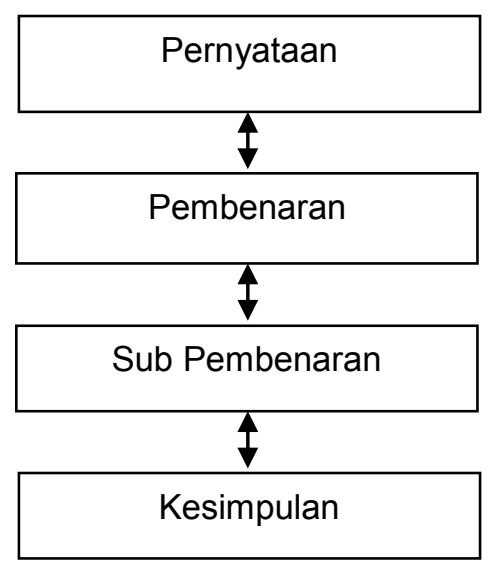

Gambar 5. Pola IV berupa Pernyataan-Pembenaran-Sub Pembenaran-Kesimpulan

Pola IV ini ditemukan pada teks 02/06/18/NIK paragraf 2, teks 03/02/21/ABS paragraf 1 , teks 03/02/21/ABS paragraf 2, teks 03/02/21/ABS paragraf 3, teks 03/02/21/ABS paragraf 4, teks 05/05/20/INR Paragraf 2, teks 05/05/20/INR paragraf 3, teks $07 / 08 / 19 /$ NS paragraf 1 , teks $07 / 08 / 19 /$ NS paragraf 3 , teks $07 / 08 / 19 / \mathrm{NS}$ paragraf 4, teks 08/08/19/CLDHP paragraf 7, teks 09/09/18/TA paragraf 3, teks 09/09/18/TA paragraf 5, teks 10/09/18/DA paragraf 1 , dan teks 10/09/18/DA paragraf 2.

\section{e. Pola Pernyataan - Pembenaran (Pola V)}

Pola $\mathrm{V}$ berupa pernyataan-pembenaran, penulis mengawali tulisannya dengan membuat pernyataan tentang ide yang akan penulis tuangkan pada setiap karya ilmiah remaja, selanjutnya penulis menyampaikan pembenaran guna mendukung pernyataan pada kalimat sebelumnya tanpa diikuti kesimpulan yang logis. Pola ini dikatakan tidak lengkap karena paragraf argumentasi terdiri dari tiga bagian penting yaitu mengandung pernyataan didukung data dan fakta yang berupa pembenaran yang dapat dipertanggungjawabkan disampaikan secara logis untuk dapat kesimpulan. Pada pola ini digambarkan sebagai berikut.

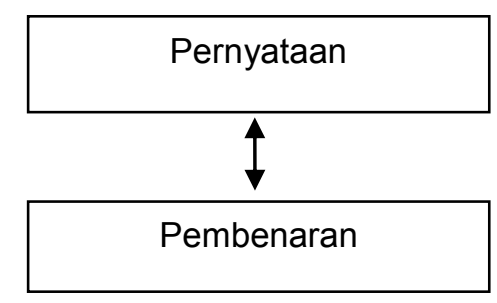

Gambar 6. Pola V Pola berupa Pernyataan-Pembenaran

Pola $V$ ini ditemukan pada teks 02/06/18/NIK Paragraf 1 , teks 02/06/18/NIK paragraf 3 , pada teks 02/06/18/NIK paragraf 1 , pada teks 02/06/18/NIK paragraf 3 , pada teks 04/02/19/PA paragraf 4, pada teks 06/05/18/ABU paragraf 2, pada teks 06/05/18/ABU paragraf 3, dan teks 08/08/19/CLDHP pada paragraf 1. 
Eka Darlina, Dian Eka Chandra Wardhana, Ria Ariesta

Kajian Retorika Struktur Argumen Karya Tulis IImiah Siswa Hasil Ekstrakurikuler Karya IImiah Remaja SMA

\section{Pembahasan}

Pola struktur argumen dalam karya ilmiah remaja (KIR) ekstrakurikuler SMA Negeri di Kota Bengkulu pada latar belakang terdapat pola yang bervariasi. Adapun pola tersebut sebagai berikut: 1) pola pernyataan, pembenaran dan kesimpulan; 2) pola pernyataan, pembenaran, kesimpulan dan subkesimpulan; 3) pola pernyataan, subpernyataan, pembenaran dan kesimpulan; 4) pola pernyataan, pembenaran, subpembenaran dan kesimpulan; sera 5) pola pernyataan dan pembenaran. Kemudian, terdapat juga paragraf yang tidak berpola atau satu T-unit saja dalam satu kalimat yang hanya berupa pernyataan dan kesimpulan saja. Adapun paragraf tidak berpola sebanyak 3 kalimat.

Elemen paragraf lengkap dan baik urutan tindak tutur pada bagian masalah (problem) mengajukan suatu klaim (claim) atau pernyataan didukung dengan suatu pembenaran (justification) yang berbentuk pengalaman, fakta, data statistik atau kejadian otentik yang bertujuan untuk mendukung pendapat penulis pada bagian akhir, penulis mengemukakan induksi (induction) atau kesimpulan logis yang diambil dari pembenaran (Connor dan Lauer dalam Safnil, 2010:48). Dengan terpolanya struktur argumen ini, maka memudahkan pembaca memahami apa yang disampaikan penulis melalui tulisannya.

Berdasarkan temuan peneliti pada pola I, penulis memulai bagian masalah (problem) dengan mengajukan suatu klaim (claim) atau pernyataan mengenai pendapat penulis untuk pembaca dan klaim didukung dengan satu pembenaran (justification) yang berbentuk pengalaman fakta statistik dan kejadian otentik yang bertujuan untuk mendukung pendapat penulis terakhir, penulis mengemukakan suatu induksi (induction) atau kesimpulan yang logis yang diambil dari pembenaran (Connor dan Lauer dalam Safnil, 2010:48). Pola ini telah memenuhi elemen-elemen argumen tulisan yang mana telah berupa pernyataan didukung pembenaran dan pada akhir kalimat terdapat kesimpulan untuk menyimpulkan pernyataan dan pembenaran sebelumnya. Dari kesepuluh teks karya ilmiah remaja SMA yang penulis analisis, pola ini muncul sebanyak 5 paragraf dari 43 paragraf atau $12 \%$. Pola ini penulis temukan pada teks 01/06/18/NIK paragraf 2, teks 06/05/18/ABU paragraf 1 , teks 07/08/19/NS paragraf 2, pada teks 08/08/19/CLDHP paragraf 6, dan teks 09/09/18/TA pada paragraf 4.

Pola II pada wacana penulisan awal penulis menyampaikan pernyataan lalu pembenaran yang berkaitan pada masalah yang diungkapkan berupa fakta-fakta yang membenarkan dari pernyataan pada akhir paragraf, penulis menyampaikan kesimpulan/induksi. Dalam analisis monolog ini menunjukkan adanya penguatan pada subkesimpulan. Hal ini ditemukan peneliti penggunaan subbagian induksi (induction) dinyatakan dalam subkesimpulan. Pola ini ditemukan penulis sebanyak 2 paragraf atau $5 \%$ yang penulis temukan pada teks 02/06/18/NIK paragraf 4 dan teks 04/02/19/PA pada paragraf 3.

Pola III dalam latar belakang karya ilmiah remaja SMA, penulis menemukan wacana tindak tutur penulis didahului penyampaian wacana penulisan berupa ide kreatif penulis, pernyataan dan sub-pernyataan didukung dengan pembenaran pada akhir kalimat penulis menyimpulkan. Pada pola ini ada sub-pernyataan yang ditemukan oleh penulis merupakan rincian pernyataan umum, dilihat dari internal bagian masalah tujuan argumentatif tidak bisa dicapai sekaligus melalui satu klaim, tetapi dengan beberapa argumen kecil atau sub-sub klaim masing-masing dengan pendukung pernyataan kemudian didukung oleh pembenaran dan induksi. Pola ini

Silampari Bisa: Jurnal Penelitian Pendidikan Bahasa Indonesia, Daerah, dan Asing

Vol. 4, No. 1, 2021 
Eka Darlina, Dian Eka Chandra Wardhana, Ria Ariesta

Kajian Retorika Struktur Argumen Karya Tulis IImiah Siswa Hasil Ekstrakurikuler Karya IImiah Remaja SMA

penulis temukan 4 paragraf atau $9 \%$ dari keseluruhan teks yang penulis analisa ditemukan pada teks 04/02/19/PA paragraf 1 dan paragraf 2 . Pola III ini juga ditemukan pada teks 05/05/20/INR paragraf 1 dan paragraf 4.

Pada pola IV penulis menyampaikan claim/pernyataan, didukung dengan pembenaran untuk lebih mendukung pembenaran dipertegas dengan beberapa subpembenaran pada akhir paragraf juga dapat dibuat kesimpulan secara umum. Penggunaan sub-pembenaran merupakan frekuensi lain dalam analisis monologis (penggunaan klaim dan pembenaran) relatif menggunakan sub-klaim maupun subpembenaran digunakan untuk penegasan ulang. Hasil analisis penulis pola ini sangat dominan yang penulis temukan yaitu 15 paragraf atau $35 \%$. Pola ini penulis temukan pada teks 02/06/18/NIK paragraf 2, pada teks 03/02/21/ABS paragraf 1,2,3,4, pada teks 05/05/20/INR paragraf 2 dan 3, pada teks 07/08/19/NS paragraf 1,3,4, pada teks 08/08/19/CLDHP paragraf 7, pada teks 09/09/18/TA 3 dan 5, dan teks 10/09/18/DA pada paragraf 1 dan 2. Temuan peneliti pada teks 03/02/21/ABS keseluruhan pola didominasi oleh pola ini.

Pada pola $\mathrm{V}$ pernyataan-pembenaran, penulis mengawali wacana penulisan dengan pernyataan berupa ide kreatif penulis. Pada kalimat kedua penulis meneruskan wacana penulisan dengan menulis pembenaran berupa data atau fakta untuk mendukung pernyataan sebelumnya, paragraf di atas hanya terdiri dari dua kalimat tanpa diikuti kesimpulan yang logis dari pernyataan dan pembenaran yang ada sangat jelas memiliki perbedaan pola dengan paragraf yang lainya. Ciri-ciri paragraf argumentasi terdiri dari tiga bagian yang paling penting, yaitu mengandung kebenaran untuk mengubah sikap dan keyakinan orang mengenai sebuah topik yang dibahas berupa atau pernyataan mengandung data atau fakta-fakta yang berupa pembenaran yang dapat dipertanggung jawabkan, serta penjelasan yang disampaikan melalui paragraf argumentasi secara logis untuk suatu kesimpulan (Noermanzah, 2018; Keraf, 2010). Terlihat jelas pernyataan yang dikemukakan diikuti dengan pembenaran, pola ini sangat sederhana secara kualitas isi maupun makna. Dari kesepuluh teks karya ilmiah remaja SMA yang penulis analisis pola ini muncul sebanyak 14 paragraf dari 43 paragraf atau 33\%. Pola ini penulis temukan pada teks 01/06/18/NIK paragraf 1 dan paragraf 3 . Selanjutnya, pola ini penulis temukan pada teks 02/06/18/NIK paragraf 1 dan 3, pada teks 04/02/19/PA paragraf 4, pada teks 06/05/18/ABU paragraf 2 dan 3, teks 08/08/19/CLDHP pada paragraf 1,2,3,4,5 dan paragraf 8 , dan teks 09/09/18/TA pada paragraf 2. Pola $V$ ini dominan ditemukan pada teks 08/08/19/CLDHP sebanyak enam dari delapan paragraf, ini menunjukkan penulis pada teks ini lemah dalam pemahaman pola paragraf argumen. Akan tetapi, pada teks 03/02/21/ABS, 05/05/20/INR, 07/08/19/CLDHP, 10/09/18/DA pola ini tidak ditemukan.

Berdasarkan hasil analisis yang penulis lakukan pada karya ilmiah remaja SMA penulis menemukan struktur argumen yang tidak berpola. Yang terdiri dari satu paragraf saja, pola ini ditemukan penulis sebanyak 3 paragraf atau $7 \%$, pola ini dapat ditemukan pada teks 09/09/18/TA paragraf 1 . Penulis mengawali dengan pernyataan tanpa adanya pembenaran dan kesimpulan, paragraf 6 penulis membuat kesimpulan tanpa didukung dengan pembenaran dan pernyataan sebelumnya, dan pada teks 10/09/18/DA paragraf 3 penulis membuat kesimpulan tanpa adanya pernyataan dan pembenaran sebelumnya.

Silampari Bisa: Jurnal Penelitian Pendidikan Bahasa Indonesia, Daerah, dan Asing Vol. 4, No. 1, 2021 
Eka Darlina, Dian Eka Chandra Wardhana, Ria Ariesta

Kajian Retorika Struktur Argumen Karya Tulis IImiah Siswa Hasil Ekstrakurikuler Karya IImiah Remaja SMA

Analisis di atas menunjukan pola $\mathrm{V}$ pernyataan-pembenaran dominan ditemukan pada karya ilmiah remaja. Menggambarkan penulis belum mengetahui elemen-elemen paragraf argumen karena pembelajaran menulis hanya pada aturan atau kaidah yang umum saja belum menyentuh hingga pada pola paragraf argumen baik pola argumen Safnil (2010) maupun Toulmin (2003) yang mana paragraf argumen minimal memiliki 3 elemen dasar yaitu pernyataan, pembenaran dan kesimpulan. Pola IV juga mendominasi temuan pada teks karya ilmiah remaja, ini menggambarkan bahwa penulis telah mempunyai kemampuan memenuhi elemen dalam paragraf argumen yang baik berdasarkan teori Bottom-Up dimana suatu paragraf argumen minimal memiliki 3 pola yakni pernyataan, pembenaran, dan kesimpulan.

Bervariasinya pola penulisan paragraf argumen dalam karya ilmiah remaja SMA disebabkan kurangnya pengetahuan penulis terhadap penulisan wacana argumentasi. Penulis belum mengenal pola paragraf argumen dan ciri-ciri paragraf argumen karena sedikitnya porsi pembelajaran pada Mata Pelajaran Bahasa Indonesia SMA yang mana pada silabus pembelajaran bahasa Indonesia kurikulum K13 pembelajaran menulis dipelajari siswa pada kelas $X$ dalam pembelajaran menulis argumentasi secara umum, tidak mendalam hingga ke elemen-elemen paragraf. Disayangkan guru pembimbing karya ilmiah remaja juga tidak menyampaikan tentang cara membuat argumen yang baik pada suatu karya ilmiah karena ketidakpahaman dan keterbatasan waktu dalam membimbing siswa dalam kegiatan ekstrakurikuler karya ilmiah remaja. Kurangnya pemahaman dan rujukan siswa tentang menulis karangan argumentasi juga mempengaruhi pola argumen siswa dalam menulis karya ilmiah menjadikan karya ilmiah remaja yang dihasilkan sangat bervariasi.

Era digital dan kemajuan teknologi saat ini dimana semakin mudahnya seseorang mengakses apa yang mereka inginkan menjadikan seseorang mengambil jalan pintas dengan menjiplak karya ilmiah maupun artikel orang lain atau plagiarisme. Penulis melakukan cek plagiarisme dengan menguji teks argumen karya ilmiah remaja pada struktur kalimat pendahuluan pada: Plagiarisme Checker penulis menemukan tingkat kesamaan tulisan atau similaritasnya pada teks 01/06/18/NIK sebesar $33 \%$, pada teks $02 / 06 / 18 / \mathrm{NIK}$ sebesar $50 \%$, pada teks 03/02/21/ABS sebesar $18 \%$, pada teks $04 / 02 / 19 / \mathrm{PA}$ sebesar $55 \%$, pada teks $05 / 05 / 20 /$ INR sebesar $9 \%$, pada teks $06 / 05 / 18 / A B U$ sebesar $33 \%$, pada teks $07 / 08 / 19 /$ NS sebesar $70 \%$, pada teks 08/08/19/CLDHP sebesar $26 \%$, pada teks 09/09/18/TA sebsar $47 \%$, dan pada teks 10/09/18/DA sebesar 42\% Plagiarisme. Hal ini sangat disayangkan, tidak sedikit penulis yang hanya melakukan copy-paste tanpa melakukan perubahan dan tidak menyertakan sumber kutipan.

Berdasarkan hasil analisis peneliti pada pembahasan di atas. Siswa dalam pembuatan karya ilmiah remaja memanfaatkan kemudahan dan canggihnya teknologi saat ini dengan mengutip berbagai sumber rujukan atau ide penulis dari situs, blog, konten maupun beberapa majalah daring seperti 1) www.academi.edu, 2) www.scribd.com, www.banksoalbiologi.com, 3) www.coursehero.com, http://repositori.iainpurwokerto.ac.id, dan 4) www.ndondon.net. Disayangkan penulis hanya melakukan copy-paste tanpa melakukan perubahan dan tidak menyertakan sumber kutipan. Plagiarisme ini terjadi dikarenakan ketidakpahaman penulis dalam mengutip sumber karya ilmiah sebelumnya. Banyaknya persentase tingkat kesamaan tulisan ini karena belum adanya batasan baku persentase pembuatan suatu karya ilmiah remaja, dan guru pembimbing karya ilmiah remaja kemungkinan mengizinkan

Silampari Bisa: Jurnal Penelitian Pendidikan Bahasa Indonesia, Daerah, dan Asing

Vol. 4, No. 1, 2021 
Eka Darlina, Dian Eka Chandra Wardhana, Ria Ariesta

Kajian Retorika Struktur Argumen Karya Tulis IImiah Siswa Hasil Ekstrakurikuler Karya IImiah Remaja SMA

mengambil rujukan atau ide penulis dari sumber-sumber dari situs, blog, konten maupun majalah-majalah online. Hal ini menyebabkan siswa dalam pembuatan karya ilmiah melakukan plagiarisme.

Berdasarkan analisis data dalam membuat karya ilmiah remaja, penulis melakukan plagiarisme khususnya pada argumen latar belakang. Plagirisme pada karya tulis ilmiah yang tidak ikut kegiatan perlombaan yaitu teks 04/02/19/PA sebesar $55 \%, 06 / 05 / 18 / A B U$ sebesar $33 \%$, 07/08/19/NS sebesar $70 \%$, dan teks 09/09/18/TA sebesar $47 \%$ sedangkan karya ilmiah remaja yang diikutsertakan dalam kegiatan perlombaan karya ilmiah dilihat pada teks 01/06/18/NIK sebesar 33\%, 02/06/18/NIK sebesar 50\%, 03/02/21/ABS sebesar 18\%, 05/05/20/INR sebesar 9\%, 08/08/19/CLDHP 26\%, dan pada 10/09/18/DA sebesar 42\%. Selain kemudahan dalam mengakses sumber-sumber rujukan juga masih terbatasnya kemampuan penulis dalam membuat suatu karya ilmiah.

Hasil penelitian pembandingan berdasarkan Toulmin's Argument Pattern (TAP) menunjukkan bahwa struktur argumen karya ilmiah remaja membentuk pola CDCDW-DQ, CD-CDWQ-BQ-CDWQ, CDWWBQ-CDWQ-CDWBBQ-CDWBQ, CDWQCDWQ-DDWB-CDWQ, CD-DW-DW-DW-CD-CDW-DWBQ-DQ dan CDDQ-CDDW-Q. Hal ini berbeda dengan model Toulmin's Argument Pattern (TAP) lengkap dimana pola argumen terdiri dari 6 elemen (claim, data, warrant, backing, qualifier, dan rebutal). Namun, telah ditemukan 1 karya ilmiah yang telah memenuhi 5 pola struktur paragraf argumen.

Penelitian ini memberikan masukan dan manfaat yang sangat berguna bagi peneliti pribadi maupun lembaga dimana penulis mengabdi. Peneliti akan mengajarkan kepada siswa dalam pembelajaran bahasa Indonesia bagaimana elemen paragraf argumen yang benar dan lengkap berdasarkan teori bottom-up, minimal mengandung elemen dasar yakni pernyataan, pembenaran, dan kesimpulan, mengajarkan teori Toulmin's Argument Pattern (TAP) yang terdiri dari claim (pernyataan), data (fakta), warrant (pembenaran), backing (dukungan), qualifier (modal), dan rebuttal (bantahan) karena pembelajaran yang ada saat ini tidak menyampaikan secara spesifik tentang elemen paragraf dalam suatu argumen (Toulmin, 2003). Kemudian, memberikan masukan pada teman sejawat pada kegaitan-kegiatan tertentu tentang temuan yang ditemukan pada penelitian ini. Mengajarkan kepada siswa untuk tidak melakukan plagiarisme tak kalah pentingnya dan dalam setiap kegiatan karya ilmiah seleksi plagiat akan peneliti lakukan. Selian itu, perulunya mengajarkan teori paragraf argumen dan membiasakan siswa untuk pembuatan suatu karya ilmiah yang baik sangat penting terlebih pada siswa yang ikut dalam ekstrakurikuler karya ilmiah remaja.

\section{Simpulan dan Saran}

Hasil penelitian ini menunjukkan bahwa struktur argumen karya tulis ilmiah siswa hasil Ektrakulikuler Karya IImiah Remaja (KIR) SMA Negeri di Kota Bengkulu berpola: 1) pernyataan, pembenaran, dan kesimpulan; 2) pernyataan, pembenaran, kesimpulan, dan subkesimpulan; 3) pernyataan, subpernyataan, pembenaran, dan kesimpulan; 4) pernyataan, pembenaran, subpembenaran, dan kesimpulan; 5) pernyataan dan pembenaran. Sebagian besar struktur argumen dalam karya tulis ilmiah sudah baik, walaupun ada yang belum lengkap terutama belum dihadirkannya kesimpulan. Hasil penelitian ini diharapkan agar ditindaklanjuti khususnya bagi pelatih

Silampari Bisa: Jurnal Penelitian Pendidikan Bahasa Indonesia, Daerah, dan Asing Vol. 4, No. 1, 2021 
Eka Darlina, Dian Eka Chandra Wardhana, Ria Ariesta

Kajian Retorika Struktur Argumen Karya Tulis IImiah Siswa Hasil Ekstrakurikuler Karya IImiah

Remaja SMA

ektrakulikuler karya ilmiah remaja SMA dan guru bahasa Indonesia untuk memberikan pemahaman kepada siswa dalam menulis paragraf argumentasi dengan menggunakan variasi pola argumen yang lengkap yaitu pernyataan, pembenaran, dan kesimpulan.

\section{Daftar Pustaka}

Abduh, N. K., Sastromiharjo, A., \& Anshori, D. S. (2019). Pola Argumentasi pada Genre Teks Eksposisi Karangan Siswa SMA. RETORIKA: Jurnal Bahasa, Sastra, dan Pengajarannya, 12(1), 71. doi:10.26858/retorika.v12i1.7372

Atmaja, H. (2016). Analisis Struktur Retorika Bagian Hasil dan Pembahasan Artikel Jurnal Bidang Berbahasa Indonesia Bidang IImu Sastra pada Jurnal "BISA" FKIP Universitas Bengkulu. Diksa: Pendidikan Bahasa dan Sastra Indonesia, 2(2), 150-156. doi:10.33369/diksa.v2i2.3412

Fitri, A. (2002). "Retorika dalam Penulisan Surat Pribadi Tahun 2001". Tesis. Bengkulu: FKIP Universitas Bengkulu.

Jauhari, H. (2018). Terampil Mengarang dari Persiapan Hingga Presentasi dari Opini Hingga Sastra. Bandung: Nuansa Cendikia.

Keraf, G. (2010). Argumentasi dan Narasi Lanjutan. Jakarta: Gramedia Utama.

Krippendorff. (1993). Analisis Isi Pengantar Teori dan Metodologi. Jakarta: Raja Grafindo Persada.

Noermanzah, Emzir, \& Lustyantie, N. (2018). President Joko Widodo's Rhetorical Technique of Arguing in the Presidential Speeches of the Reform Era. International Journal of Applied Linguistics and English Literature, 7(5), 119. doi:10.7575/aiac.ijalel.v.7n.5p.117

Noermanzah, N., Emzir, E., \& Lustyantie, N. (2017). Variety of Rhetorics in Political Speech President of the Republic of Indonesia Susilo Bambang Yudhoyono and Joko Widodo in Educational Field. Humanus, 16(2), 221. doi:10.24036/humanus.v16i2.8103

Noermanzah, Wahyuni, S., Astuti, T., Wardhana, D. E. C., \& Syafryadin. (2020). The Rhetorical Structure of the Lubuklinggau Mayor's Speech in Building Community Trust. Retrieved from osf.io/j8p9t. International Journal of Progressive Sciences and Technologies (IJPSAT), 19(2).

Safnil. (2010). Pengantar Analisis Retorika Teks. Bengkulu: FKIP UNIB Press.

Sugiyono. (2017). Metode Penelitian Kuantitatif, Kualitatif dan R\&D. Bandung: Alfabeta. 
Eka Darlina, Dian Eka Chandra Wardhana, Ria Ariesta

Kajian Retorika Struktur Argumen Karya Tulis IImiah Siswa Hasil Ekstrakurikuler Karya IImiah

Remaja SMA

Sulistyarini, D. \& Zainal, A. G. (2020). Buku Ajar Retorika. Serang Banten: CV. AA Rizki.

Suparno. (2017). Konstruktivisme dalam Pendidikan. Yogyakarta: Kanisius.

Susetyo. (2010). Penelitian Kuantitatif dan Kualitatif Pengajaran Bahasa dan Sastra Indonesia. Bengkulu: FKIP UNIB.

Toulmin, S. E. (2003). The Uses Of Argumen. New York: Cambridge University Press.

Trianto, A. (2000). "Retorika Humor Mahasiswa Tahun 2000 (Laporan Penelitian)". Bengkulu: FKIP Universitas Bengkulu.

Trianto, A. (2009). Kajian Retorika Tulisan Kolom. Jakarta: Kolita Internasional.

Yati, D. (2018). "Pola dan Kadar Ketajaman Argumen Bagian Hasil Penelitian dan Pembahasan pada Artikel Mahasiswa Program Magister (S2) Pendidikan Bahasa Indonesia FKIP Universitas Bengkulu Tahun Ajar 2016/2017". Tesis. Bengkulu: FKIP Universitas Bengkulu.

Silampari Bisa: Jurnal Penelitian Pendidikan Bahasa Indonesia, Daerah, dan Asing Vol. 4, No. 1, 2021 